\title{
Lower Aeronian (Llandovery, Silurian) graptolitic carbonate concretions from the Qusaiba Shale Formation, Tabuk Basin, Saudi Arabia, and their significance
}

\author{
DaVid K. Loydell \& Mohamed Abouelresh
}

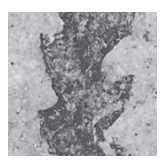

\begin{abstract}
A unique layer of carbonate concretions within the Qusaiba Shale Formation, north-west of Tayma in north-west Saudi Arabia, is dated to the early Aeronian (within the lowermost magnus Biozone, close to the triangulatus/magnus Biozone boundary) based upon its diverse (18 species) assemblage of graptolites. This assemblage is dominated by biserial taxa, many showing current alignment. The studied concretion included a $6 \mathrm{~mm}$ thick layer composed entirely of graptolites, potentially significant, if laterally extensive, for the burial of organic carbon. Carbonates of a similar age occur in northernmost Saudi Arabia, suggesting that the concretions may be a useful stratigraphical marker and are likely to result from similar environmental conditions. A few localities on Avalonia and Baltica, in sections otherwise dominated by outer shelf or basinal clastics, also have limestone layers/concretions and/or unusually high incidences of preservation of shells (mostly orthocones) within the lower Aeronian. It is considered likely that the limestone layers and concretions resulted from dissolution then reprecipitation of carbonate from some of the shelly fauna. This may be a stratigraphically very early and poorly developed expression of the cephalopod limestone facies so characteristic of higher levels in the Silurian of peri-Gondwanan Europe and Gondwana. The deposition/preservation of the limestones occurred within the positive Early Aeronian Carbon Isotope Excursion (EACIE) which itself may reflect an interval of slightly lower eustatic sea-level. One new graptolite species, Paraclimacograptus crameri, is described, distinguished from $\mathrm{Pa}$. libycus by its narrower rhabdosome. - Key words: Silurian, Aeronian, graptolite, concretions, carbon isotopes, Saudi Arabia, Qusaiba Shale, Gondwana.
\end{abstract}

Loydell, D.K. \& Abouelresh, M. 2021. Lower Aeronian (Llandovery, Silurian) graptolitic carbonate concretions from the Qusaiba Shale Formation, Tabuk Basin, Saudi Arabia, and their significance. Bulletin of Geosciences 96(3), 251-263 (6 figures). Czech Geological Survey, Prague. ISSN 1214-1119. Manuscript received July 15, 2020; accepted in revised form May 14, 2021; published online May 30, 2021; issued July 4, 2021.

David K. Loydell, School of the Environment, Geography and Geosciences, University of Portsmouth, Burnaby Road, Portsmouth PO1 3QL, UK; david.loydell@port.ac.uk • Mohamed Abouelresh, Center for Environment \& Water, TI, King Fahd University of Petroleum and Minerals, Saudi Arabia, on sabbatical leave from Faculty of Petroleum \& Mining Engineering, Suez University, Egypt

The Qusaiba Shale Formation, of Llandovery (early Silurian) age, is the most prolific Palaeozoic source rock in Saudi Arabia. The recent discovery of a conspicuous horizon of graptolitic carbonate concretions within the lower, organic-rich part of the formation in an outcrop section in the Tabuk Basin, north-west Saudi Arabia (Abouelresh et al. 2020) is very important in demonstrating for the first time the presence of a distinctive marker layer within a sequence otherwise dominated by laminated green, dark grey and black shales.

The aims of this paper are to describe the graptolite assemblage from this newly discovered concretionary layer, discuss the biostratigraphical significance of the graptolites, highlight the existence of similar diagenetic carbonates and shelly fossils at similar stratigraphical levels elsewhere and then briefly discuss these occurrences in relation to the carbon isotope record from other localities and previously identified eustatic Llandovery sea-level changes (Loydell 1998, 2007a).

\section{Depositional setting}

The studied locality lies on the Arabian shelf in the north-western part of the Arabian Plate, to the north and east of the Arabian shield (Fig. 1D). This area lay at approximately $45^{\circ}$ South during the Llandovery (Torsvik $\&$ Cocks 2013). The locality is within the Tabuk Basin (Abouelresh et al. 2020). This basin was referred to as the Nafud Basin by both Lüning et al. (2000) and Aoudeh \& Al-Hajri (1995), who separated it into two sub-basins: the Tabuk-Tayma embayment and 'Ar' ar Al-Jawf sub-basin. 

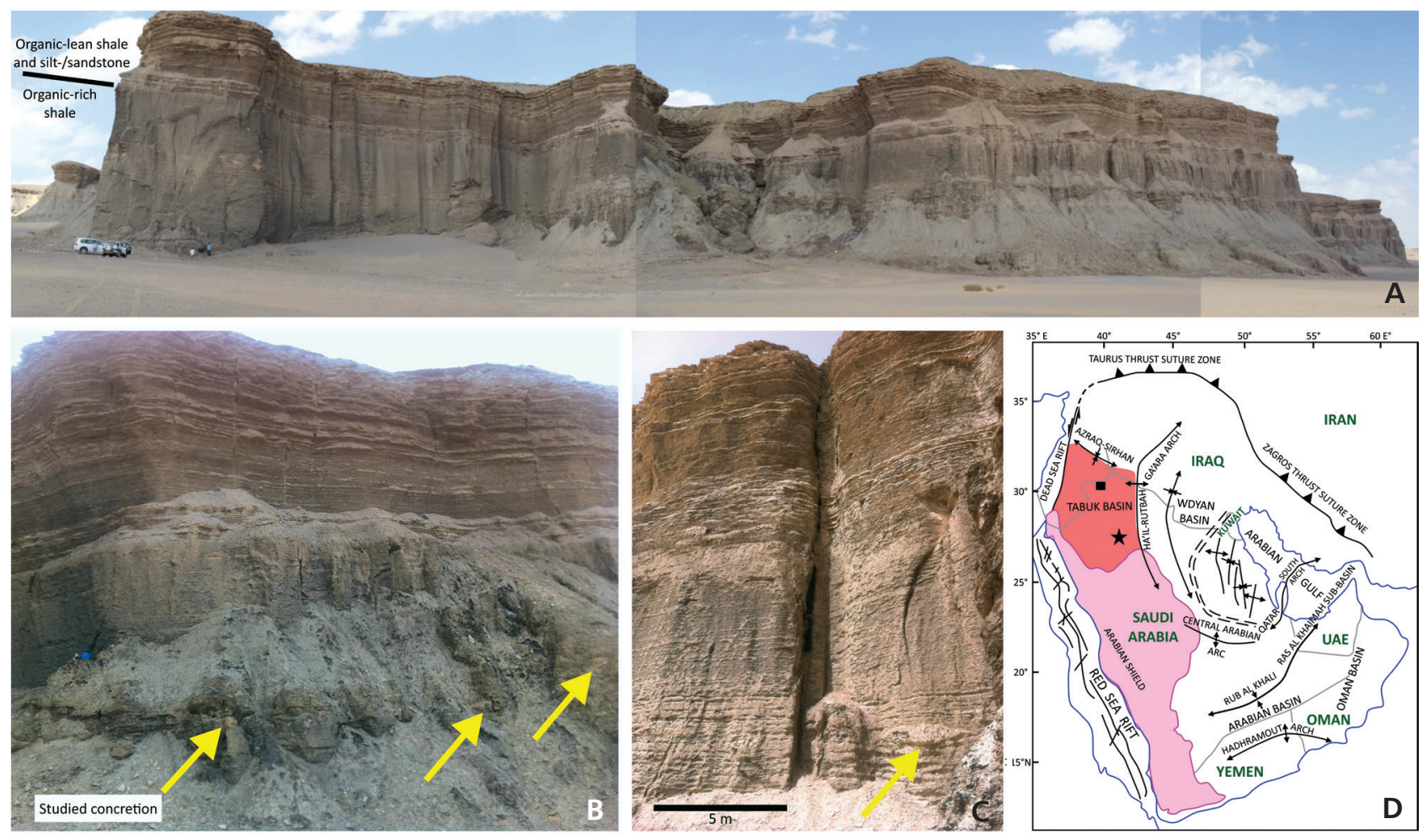

Figure 1. A - the outcrop section of the Qusaiba Shale Formation described by Abouelresh et al. (2020) in the ridge forming the north-west margin of the Tayma Graben, north-west of Tayma City, Saudi Arabia, containing the concretionary horizon studied herein. See right hand side of Figure 2 for $\log$ of section. $\cdot \mathrm{B}$ - concretionary horizon, with collected concretion arrowed. People (one in blue shirt) for scale. $\bullet \mathrm{C}-$ lateral continuation of concretionary horizon. $\cdot \mathrm{D}$ - map showing major geological structures within the Arabian Plate and location of studied section (star). Also shown (rectangle close to northern border of Saudi Arabia) is area studied by Hayton et al. (2017) referred to in the text. Map modified from Abouelresh et al. (2020).

\section{Previous stratigraphical work}

Mahmoud et al. (1992) described the reference outcrop section (Fig. 2) of the Qalibah Formation (now Group; see Halawani et al. 2013) between Al Qalibah and Tayma and thus in the same geographical area as the section studied by Abouelresh et al. (2020) that includes the carbonate concretionary horizon discussed herein. The Qusaiba Shale was at that time referred to as the lower member of the Qalibah Formation. Mahmoud et al. (1992) recorded the Qusaiba Shale as $256 \mathrm{~m}$ thick, with the lower $150 \mathrm{~m}$ being graptolitic. Above this level the strata are described (Mahmoud et al. 1992, fig. 6) as "devoid of graptolite fauna" (Fig. 2). Mahmoud et al. (1992) noted that the Qusaiba Shale includes a basal black, euxinic "hot shale" up to $70 \mathrm{~m}$ thick (Aoudeh \& Al-Hajri 1995 stated approximately $53 \mathrm{~m}$ maximum thickness at Tayma), but this "hot shale" is usually 9-31 m thick (Abouelresh et al. 2020). Mahmoud et al.'s (1992, fig. 8) palaeogeographical reconstruction shows the depositional area to have been approximately $225 \mathrm{~km}$ offshore from the littoral to nonmarine facies of the Arabian Shield. The depositional environment of the Qusaiba Shale is described as "shoreface to outer shelf": lithologically, it shows an overall coarsening upwards trend (Fig. 2), with shale predominating in its lower, organic-rich part deposited on a "mud shelf", and siltstones and fine sandstones dominating in its upper part representing the shoreface (Mahmoud et al. 1992, fig. 3).

Legrand (in Mahmoud et al. 1992) provided a range chart of graptolites from the reference outcrop section. Most specimens were left in open nomenclature (i.e. identified questionably or to genus only). The lower $30 \mathrm{~m}$ yielded Dimorphograptus and Cystograptus vesiculosus (Fig. 2) and therefore are demonstrably of mid or late Rhuddanian age. Monograptus [now Demirastrites] triangulatus (Harkness) appears $92.6 \mathrm{~m}$ from the base of the section and occurs up to the point where the section becomes non-graptolitic at $150 \mathrm{~m}$. These biostratigraphical data make it clear that the basal "hot shale" here is of Rhuddanian (but not early Rhuddanian) age and that the $31 \mathrm{~m}$ thick section studied by Abouelresh et al. (2020) must be above this Rhuddanian basal "hot shale". It would seem very likely indeed that the boundary between Abouelresh et al.'s (2020) massive dark grey to black organic-rich shale and overlying green, purple and brownish organiclean shale is equivalent to the $150 \mathrm{~m}$ level of Mahmoud et al. (1992). Chitinozoans from the Qusaiba Shale of well NWA8, near Tayma (Aoudeh \& Al-Hajri 1995, fig. 2), were 

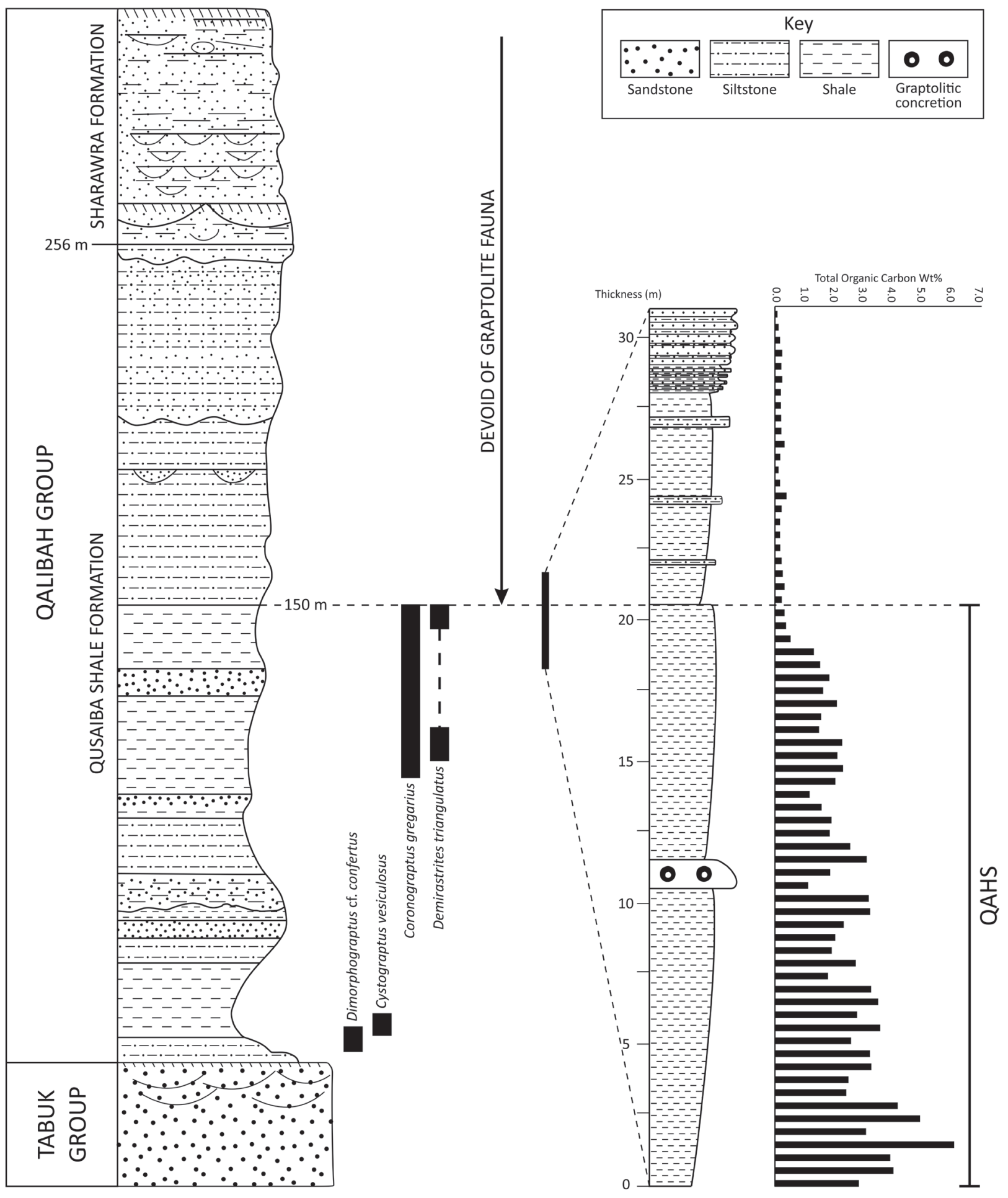

Figure 2. The Qalibah Group reference section (between Al Qalibah and Tayma) of Mahmoud et al. (1992) with ranges of the biostratigraphically important graptolites identified by Legrand (in Mahmoud et al. 1992) shown. The base of the Aeronian Stage is marked by the FAD of Demirastrites triangulatus; the co-occurrence of Cystograptus vesiculosus and Dimorphograptus near the base of the Qusaiba Formation indicates that these strata are of either mid Rhuddanian Cystograptus vesiculosus or late Rhuddanian Coronograptus cyphus Zone age. The black bar shows the stratigraphical extent of the section illustrated in Figure 1A at the same scale as Mahmoud et al.'s (1992) log, which is then expanded to the right to show lithologies and total organic carbon (TOC) content. The boundary between organic-rich, graptolitic and organically lean, non-graptolitic shale has been used for correlation - this correlation is strongly supported by the graptolite biostratigraphy. Note the horizon of the concretionary layer from which all of the graptolites described herein are sourced. Abbreviation: QAHS = Qusaiba Aeronian hot shale; this was first recognised by Hayton et al. (2017) in northernmost Saudi Arabia (see Fig. 1D for locality). 
stated to indicate a late Rhuddanian to early Aeronian age, consistent with Legrand's graptolite data.

Previous work on the graptolites of Saudi Arabia is summarized in Williams et al. (2016) who provided range charts for more than 150 species of Llandovery graptolites from 132 cores, assigning the graptolite assemblages to 11 biozones. For operational confidentiality reasons, details of cores and horizons could not be provided. The lower Aeronian, the interval of relevance to the present paper, was divided into a Demirastrites triangulatus Biozone overlain by a Neodiplograptus [now Rickardsograptus] thuringiacus Biozone. The triangulatus Biozone was characterized by the presence of $D$. triangulatus sensu lato (the triangulate monograptids show considerable variation; they have recently been revised by Štorch \& Melchin 2018), Pribylograptus incommodus, Paraclimacograptus libycus, Rhaphidograptus toernquisti and, in the upper part of the biozone, Rastrites longispinus. Williams et al. (2016, p. 18) stated that the triangulatus Biozone "typically occupies a succession of about $2 \mathrm{~m}$ of black mudstones in Saudi Arabia." This is very different from the $57 \mathrm{~m}+$ thickness suggested by Legrand's (in Mahmoud et al. 1992) data, and the implication is that this part of the Tabuk Basin hosts an unusually thick sequence of Llandovery strata. The overlying thuringiacus Biozone (0.3-9 m thick) was considered by Williams et al. (2016) to be correlative with the Neodiplograptus magnus Biozone of the British Isles, although Ne. magnus has subsequently been shown to have a significantly lower appearance than $R$. thuringiacus in the Hlásná Třebaň section, Czech Republic (Štorch et al. 2018, fig. 4). Williams et al. (2016) recorded high graptolite diversity (28 species) from the thuringiacus Biozone, with the range of $D$. triangulatus sensu lato extending to the top of the biozone. Assemblages from both lower Aeronian biozones (and the Llandovery as a whole) included both geographically restricted taxa (such as Pa. libycus) and those (the majority) with a much more widespread distribution.

Williams et al. (2016) stated that, in general, boreholes in north-west Saudi Arabia penetrated black shale successions recording continuous deposition on a distal marine shelf. Here graptolite assemblages were diverse, contrasting with the lower diversity (including stratigraphically long-ranging species) of central and eastern Saudi Arabia (and topographic highs in the north-west). Graptolite rhabdosomes within these low diversity assemblages were often current-aligned.

Hayton et al. (2017) analysed in detail the Qusaiba Shale in northern Saudi Arabia, close to the borders with Iraq and Jordan (Fig. 1D). Within this they recognised a Qusaiba Aeronian hot shale (QAHS) within the triangulatus and lower magnus biozones with a maximum TOC of $14 \%$ at its base, but with TOC values mostly between 6 and 7\%. Given the TOC values (up to
$6.1 \%$; Fig. 2) of the lower part of the outcrop section studied by Abouelresh et al. (2020) and its comparable biostratigraphical level (see below), it seems very likely that that the QAHS can also be recognised further south in the Tabuk Basin (Fig. 1D). The thickness of the QAHS in northern Saudi Arabia is approximately 9 feet $(2.75 \mathrm{~m})$ with the overlying unfossiliferous beds approximately 10 feet $(3.05 \mathrm{~m})$ thick before the first appearance of leptotheca Biozone graptolites (Hayton et al. 2017). There is therefore a maximum of $5.8 \mathrm{~m}$ of combined triangulatus and lower magnus biozones, comparable to Williams et al.'s (2016) thickness data referred to above, and again very different from that recorded by Legrand (in Mahmoud et al. 1992) from the Qalibah Group reference outcrop section between Al Qalibah and Tayma.

\section{Section details}

The studied $31 \mathrm{~m}$ thick section (Figs 1A, 2), exposed at $27^{\circ} 52^{\prime} 57.19^{\prime \prime} \mathrm{N}, 38^{\circ} 31^{\prime} 44.86^{\prime \prime} \mathrm{E}$, within a $3 \mathrm{~km}$ long ridge forming the north-west margin of the Tayma Graben, north-west of Tayma City, was described by Abouelresh et al. (2020, fig. 2) and consists (working upwards) of $10.5 \mathrm{~m}$ of organic-rich shale (maximum TOC $6.1 \%$, average $3.17 \%$ ), a layer of discontinuous graptolitic carbonate concretions between $10.5 \mathrm{~m}$ and $11.5 \mathrm{~m}$ (Fig. 1B, C), then organic-rich shale again (maximum TOC 3.09\%, average $1.87 \%$ ) up to $20.5 \mathrm{~m}$ above the base of the section, which is overlain by $7.5 \mathrm{~m}$ of organic-lean shale which coarsens up at its top to intercalated beds of siltstone/shale and then siltstone/sandstone which make up the remainder of the section (Fig. 2). Descriptions of the various lithofacies present in the section together with inorganic geochemical analyses are presented by Abouelresh et al. (2020) to which the reader is directed for further information.

The calcareous graptolitic concretionary layer identified by Abouelresh et al. (2020) is approximately $1 \mathrm{~m}$ thick, with its top $9 \mathrm{~m}$ below the top of the organic-rich shale (Fig. 2). Field, hand specimen and thin section photographs of the concretions are provided by Abouelresh et al. (2020, fig. 3e-h). The concretions are traversed by numerous branching calcite and pyrite veins. These, and other fractures within the rocks in the section, are discussed and illustrated by Abouelresh \& Babilola (2020; their figs $4 \mathrm{c}, 9 \mathrm{~b}$ are field and thin section photos of concretions respectively).

\section{Methods}

On seeing the graptolites illustrated in the nodules by Abouelresh et al. (2020), the first author contacted the second author who then shipped previously collected 

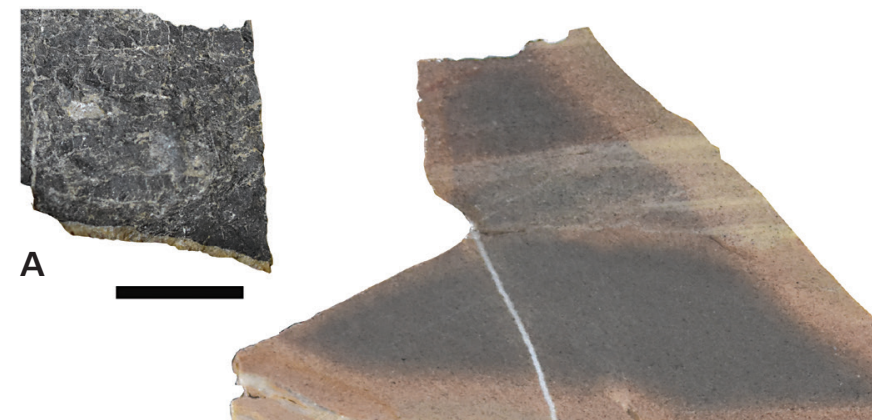

B
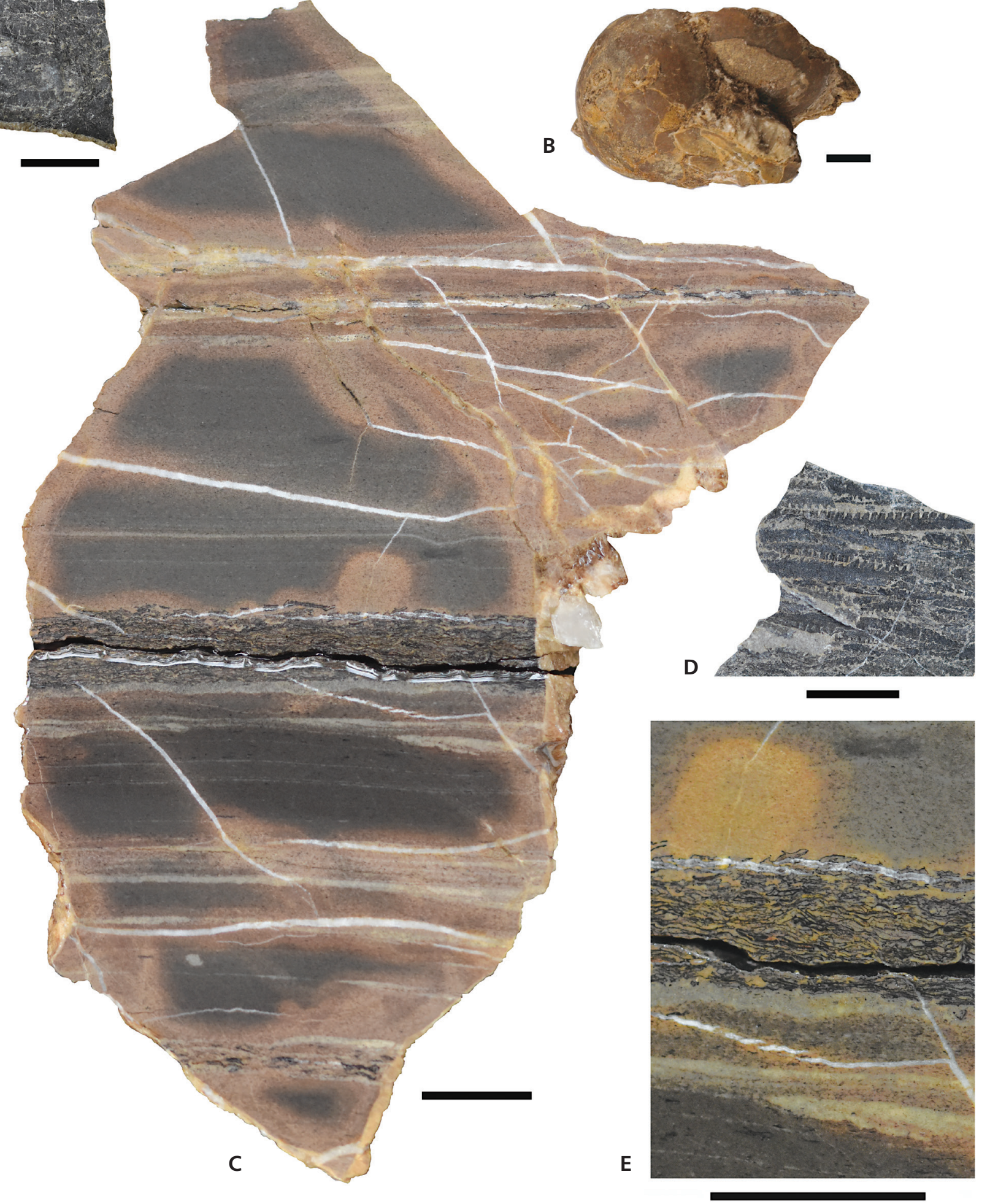

Figure 3. Lithological specimens and orthocones from the carbonate concretionary layer. $\bullet$ A - bedding surface of the $6 \mathrm{~mm}$ thick graptolite-rich layer shown in cross section in Fig. 3E; rhabdosomes are so numerous that individual graptolites are unidentifiable. $\bullet$ B - internal mould of orthocone chamber. $\cdot \mathrm{C}$ - cut and polished relatively unweathered core to the concretion shown in Fig. 1B; note extensive veining, conspicuous lamination, and the graptolite-rich layer. $\bullet \mathrm{D}$ - part of bedding surface showing current aligned biserial graptolites. $\bullet$ E - close-up of the graptolite-rich layer; note that these graptolites are preserved in low relief; all others within the nodule are flattened. All scale bars represent $10 \mathrm{~mm}$. In Figure $3 \mathrm{C}$ and $\mathrm{E}$ the sample was submerged in water to emphasize colours and contrast; as a result, some reflection is present along the broken edges of the nodule along the richly graptolitic horizon. 
material from the concretionary layer to the University of Portsmouth for study. The relatively unweathered core of one concretion was cut and polished (Fig. 3C). The remainder of the concretion was split to reveal graptolites that were studied and photographed using a Leica binocular microscope. The heavily weathered material surrounding the core to the concretion was examined also and yielded the orthocone material (Fig. 3B).

It was hoped that dissolution of pieces of nodule in dilute (10\%) acetic acid would yield identifiable graptolite fragments, conodonts (sometimes very abundant in such limestones; Lubeseder 2008, p. 205 quotes 50-400 conodont elements per $\mathrm{kg}$ ) and other phosphatic fossils. The residues, however, contained no identifiable fossils.

\section{The concretions and their fossil content}

The concretions were described as syngenetic or early diagenetic in origin by Abouelresh et al. (2020), who suggested that they formed close to the sediment/water interface at a time of no deposition or low sedimentation rate. The fact that, with the exception of the low relief specimens in the $6 \mathrm{~mm}$ thick graptolite-rich layer (Fig. 3E), all graptolites are flattened (three dimensional graptolites are well-known from very early diagenetic nodules from, for example, Sweden and Arctic Canada; see e.g. Loydell $\&$ Maletz 2004, Melchin 1998) presumably indicates the presence of overlying sediment causing compression of the graptolite rhabdosomes before concretion growth commenced.

Within the unweathered core of the studied polished concretion, the fracturing obscures original lithological details in places, but the lamination, resulting from variations in grain size, composition, and organic content, can be clearly seen (Fig. 3C).

The abundance of graptolites within the available samples is very variable. One $6 \mathrm{~mm}$ thick layer (Fig. 3E) contains so many graptolites that bedding surfaces are black, with individual graptolites almost impossible to distinguish; Fig. 3A). As noted by Loydell (2007a, p. 539) and Loydell \& Large (2019, p. 321), if laterally extensive, such layers represent the synchronous burial of a considerable amount of organic carbon. Other layers (e.g. Fig. 3D) contain abundant, current aligned graptolites (such as were illustrated by Abouelresh et al. 2020, fig. 3g), with at least some specimens identifiable. Other layers lack graptolites or they occur in very small numbers.

In addition to the graptolites, there are much less common, poorly preserved articulate (possibly pseudoplanktic) brachiopods a few $\mathrm{mm}$ in maximum size, together with several internal moulds of orthocone chambers (Fig. 3B). These are up to $4 \mathrm{~cm}$ in diameter. Orthoconic cephalopods have previously been reported from the Qusaiba Shale of north-west Saudi Arabia (e.g. by Helal 1964, in which the Qusaiba Shale was referred to as the "Climacograptus-Orthoceratid Member"; by McClure 1988, p. 161, who referred to them being "more common and robust" than in Ordovician shales; and by Williams et al. 2016, p. 22).

\section{The graptolite assemblage and its significance}

Identifiable graptolites total approximately 100 specimens. The assemblage is dominated by biserial graptolites uniserial taxa are rare, each identified species being represented by a single specimen. Diversity is quite high with 17 species identified (including one new species). These are illustrated in Figures 4 and 5. Additionally there is a small fragment (not illustrated) of either Pernerograptus or Pribylograptus resulting in a total diversity of 18 . Williams et al. (2016, p. 20) noted that in the graptolite assemblages from boreholes in NW Saudi Arabia diversity was often comparably high to that seen in the material described herein, but with uniserial (often spirally coiled) species being characteristic. This was not seen in our material, perhaps a result of sorting during transport and deposition.

Figured graptolites are housed in the British Geological Survey Keyworth (prefix BGS). The graptolite species present (all identifiable material is illustrated in Figs 4 and 5) include Gondwanan endemics, particularly Paraclimacograptus libycus (Desio) (Fig. 4M), which is by far the most common species present, together with taxa that are generally restricted to core Gondwana and periGondwanan terranes, such as Neodiplograptus fezzanensis (Desio) (Fig. 4F), and also those with a much

Figure 4. Graptolites from carbonate concretion in the Qusaiba Shale Formation. - A - Glyptograptus varians Packham, BGS FOR 6307. • B - Glyptograptus perneri Štorch, BGS FOR 6308. • C - Rhaphidograptus toernquisti (Elles \& Wood), BGS FOR 6309. • D - Normalograptus medius (Törnquist), BGS FOR 6310. • E, O - Neodiplograptus peggyae Cullum \& Loydell; E - BGS FOR 6311; O - BGS FOR 6321.・F - Neodiplograptus fezzanensis (Desio), BGS FOR 6312. • G - Metaclimacograptus serus (Paškevičius), BGS FOR 6313. • H - Neodiplograptus magnus (Lapworth), BGS FOR 6314. • I - Neodiplograptus posterior (Legrand), BGS FOR 6315. • J - “Monograptus" capis Hutt, BGS FOR 6316. • K - Normalograptus ajjeri (Legrand), BGS FOR 6317. • L - Normalograptus rectangularis (McCoy), BGS FOR 6318. • M - Paraclimacograptus libycus (Desio), BGS FOR 6319. • N - Demirastrites triangulatus (Harkness) or Demirastrites campograptoides Štorch \& Melchin, BGS FOR 6320. • P - Campograptus rostratus (Elles \& Wood), BGS FOR 6322. 

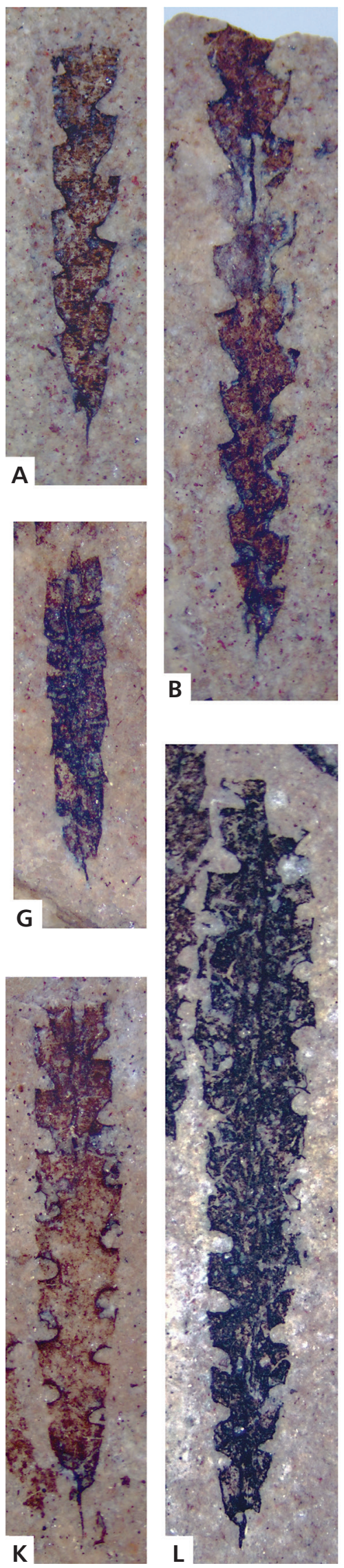
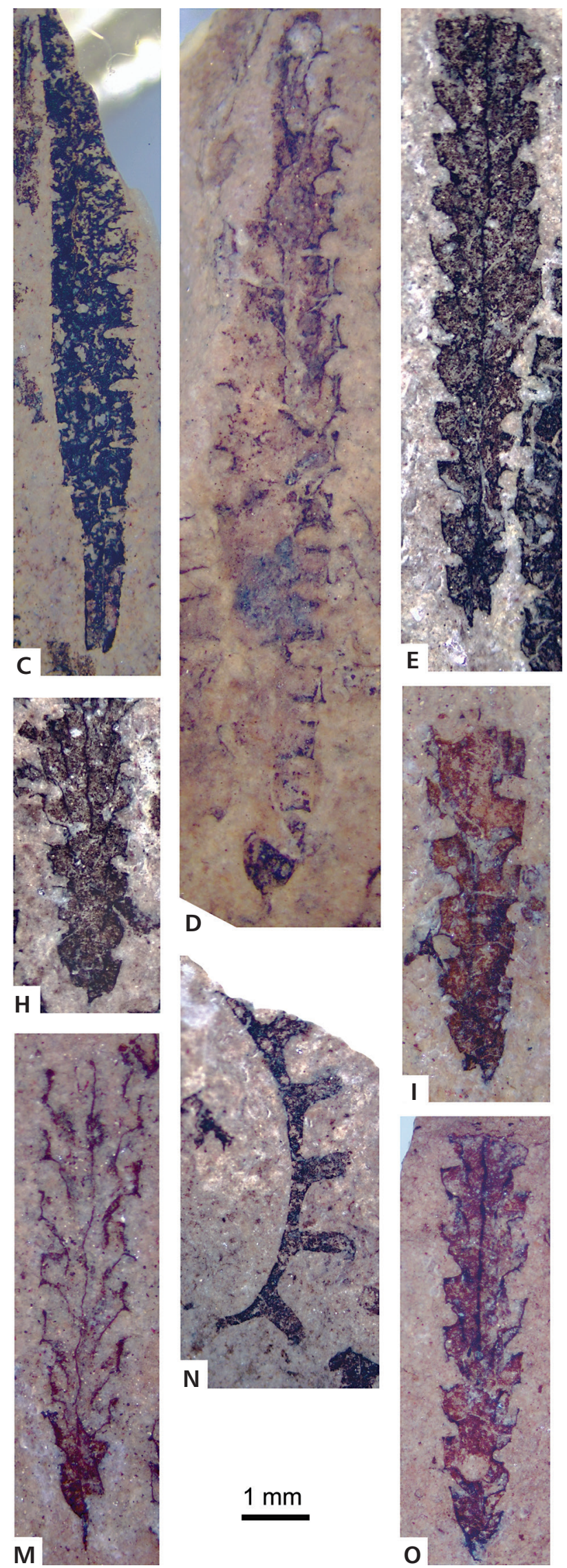

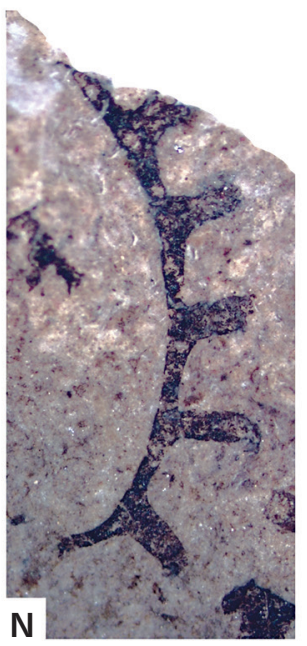

$1 \mathrm{~mm}$
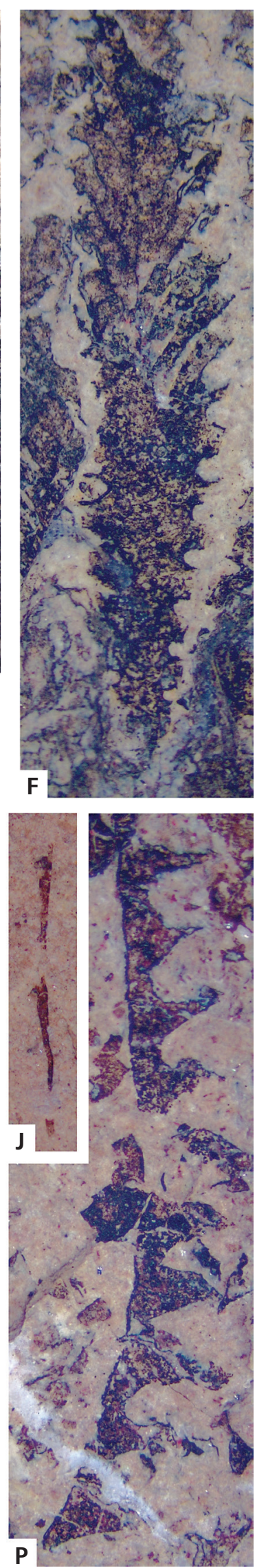


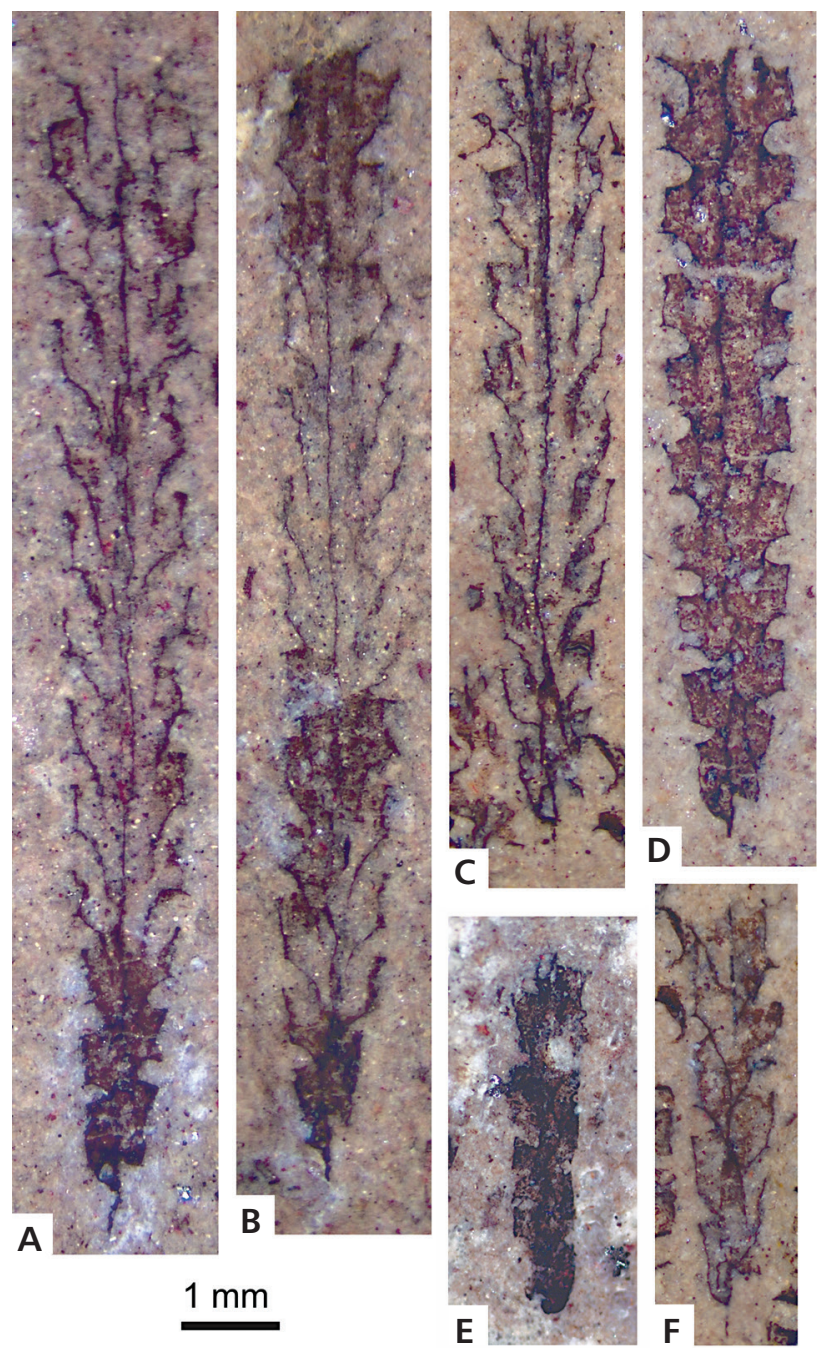

Figure 5. Graptolites from a carbonate concretion in the Qusaiba Shale Formation. - A-D, F - Paraclimacograptus crameri sp. nov.; A - BGS FOR 6323; B - BGS FOR 6324; C - BGS FOR 6325; D BGS FOR 6326; F - BGS FOR 6328. • E - Metaclimacograptus slalom Zalasiewicz, BGS FOR 6327.

more widespread distribution, extending to Avalonia and beyond, for example Rhaphidograptus toernquisti (Elles \& Wood) (Fig. 4C), Normalograptus medius (Törnquist) (Fig. 4D) and Neodiplograptus peggyae Cullum \& Loydell (Fig. 4E, O).

Detailed descriptions of most taxa present can be found in recent publications (e.g. Štorch \& Massa 2006; Loydell 2007b, 2011; Štorch 2015) and therefore are not included here. Two species present in the samples [Glyptograptus varians (Fig. 4A) and Metaclimacograptus serus (Fig. $4 \mathrm{G})$ ] have rarely been recorded since they were originally described (by Packham 1962 and Paškevičius 1976 respectively), but the figured material agrees very well indeed with the original descriptions.

The stratigraphical ranges of the species present enable assignment of the concretionary layer to a level within the lower Aeronian close to the boundary between the Demirastrites triangulatus and Neodiplograptus magnus biozones of the British biozonation. Williams et al. (2016) recognised a Neodiplograptus [now Rickardsograptus] thuringiacus Biozone above the triangulatus Biozone in Saudi Arabia, but Rickardsograptus thuringiacus (Kirste) was not encountered within our collections whereas $\mathrm{Ne}$. magnus (Lapworth) (Fig. 4H) was. The key taxa present from a biostratigraphical viewpoint are: Neodiplograptus fezzanensis (Desio), the range of which extends from the middle Rhuddanian into the lower Aeronian and to within $5 \mathrm{~cm}$ of the FAD of Ne. magnus in the Hlásná Třebaň section, Bohemia (Štorch et al. 2018); the genus Demirastrites (Fig. 4N), which first appears at the base of the Aeronian (Štorch \& Melchin 2018); Ne peggyae, previously known only from the Ne. magnus Biozone of Wales (Cullum \& Loydell 1996); and Ne. magnus itself, which gives its name to a biozone in Britain (which has strata barren of graptolites both above and below). In the Czech Republic the triangulatus Biozone is succeeded by a Demirastrites pectinatus Biozone with the FAD of Ne. magnus approximately a third of the way through the triangulatus Biozone there. Thus, using the British biozonation (Fig. 6), the Saudi graptolite concretions would be assigned to the lowermost magnus Biozone and using the Czech biozonation they would lie within the middle triangulatus Biozone.

\section{Discussion}

\section{Other occurrences of lower Aeronian carbonates and/or shelly fossils within graptolitic clastic outer shelf and basinal sequences}

Mahmoud et al. (1992, p. 1501) stated that there is an "absence of carbonates in the Silurian sequence of the Arabian plate". Subsequently, however, Ghavidel-Syooki et al. (2011) described "embedded centimetre- to metrethick carbonate concretions" within the "monotonous black to greyish shale succession" of the (upper Hirnantian to Llandovery) Sarchahan Formation of the Zagros Mountains, Iran on the north-east margin of the Arabian Plate. Whether these carbonate concretions occur throughout the formation or are stratigraphically restricted is not made clear, although their figure 2 shows a single nodular horizon (biozone not stated) in the lower Sarchahan Formation of the Kuh-e Faraghan section. The same figure also shows "carbonate siltstones" within the middle Sarchahan Formation of the Kuh-e Gahkum section which must be late Aeronian or younger in age based upon the graptolites identified by Suyarkova (in Ghavidel-Syooki et al. 2011) from underlying horizons 
and thus cannot be correlative with the concretionary layer being described herein.

Much closer to our studied section, Hayton et al. (2017) recorded the presence of calcitic horizons within the lower Aeronian of northern Saudi Arabia close to the borders with Iraq and Jordan (Fig. 1D); one is shown on their figure 8 close to the boundary between the triangulatus and magnus biozones and thus at an identical level to the carbonate nodules from our outcrop section (Fig. 6). In these Arabian Plate examples, the carbonates occur in an otherwise entirely clastic sequence. The fact that the two Saudi examples occur at the same stratigraphical level suggests a comparable and widespread environmental change at this time.

Interestingly, carbonates or unusually shelly horizons are also developed within outer shelf or basinal sequences in the lower Aeronian of Avalonia and Baltica (Fig. 6). In the Rheidol Gorge section, Wales (Avalonia) Challinor (1928) described an approximately $7.5 \mathrm{~cm}$ thick "shelly band in graptolitic shales" remarkable for its abundance of orthocones, with rare other shelly fossils, mostly bivalves. This occurs within the Demirastrites triangulatus Biozone, 6 feet $(1.83 \mathrm{~m})$ below a layer of calcareous nodules. Nothing comparable is present within the remainder of the Aeronian of the Rheidol Gorge section (Jones 1909).

Bjerreskov (1975) described in detail the Llandovery strata and fossils of Bornholm (Baltica). Within the Aeronian, limestones occur only within the triangulatus Biozone (visible also in the Sommerodde- 1 core studied by Loydell et al. 2017). A conspicuous increase in shelly fossils (bivalves, brachiopods and orthocone cephalopods) is recorded from the pectinatus Biozone. Neither limestones nor shelly fossils (transported or in situ) are recorded from higher levels in the Aeronian.

The upper Rhuddanian-upper Aeronian Dobele Formation of Latvia (Baltica) comprises dark grey to black graptolitic shales, apart from a $0.7 \mathrm{~m}$ thick limestone with its base in the middle of the triangulatus Biozone;

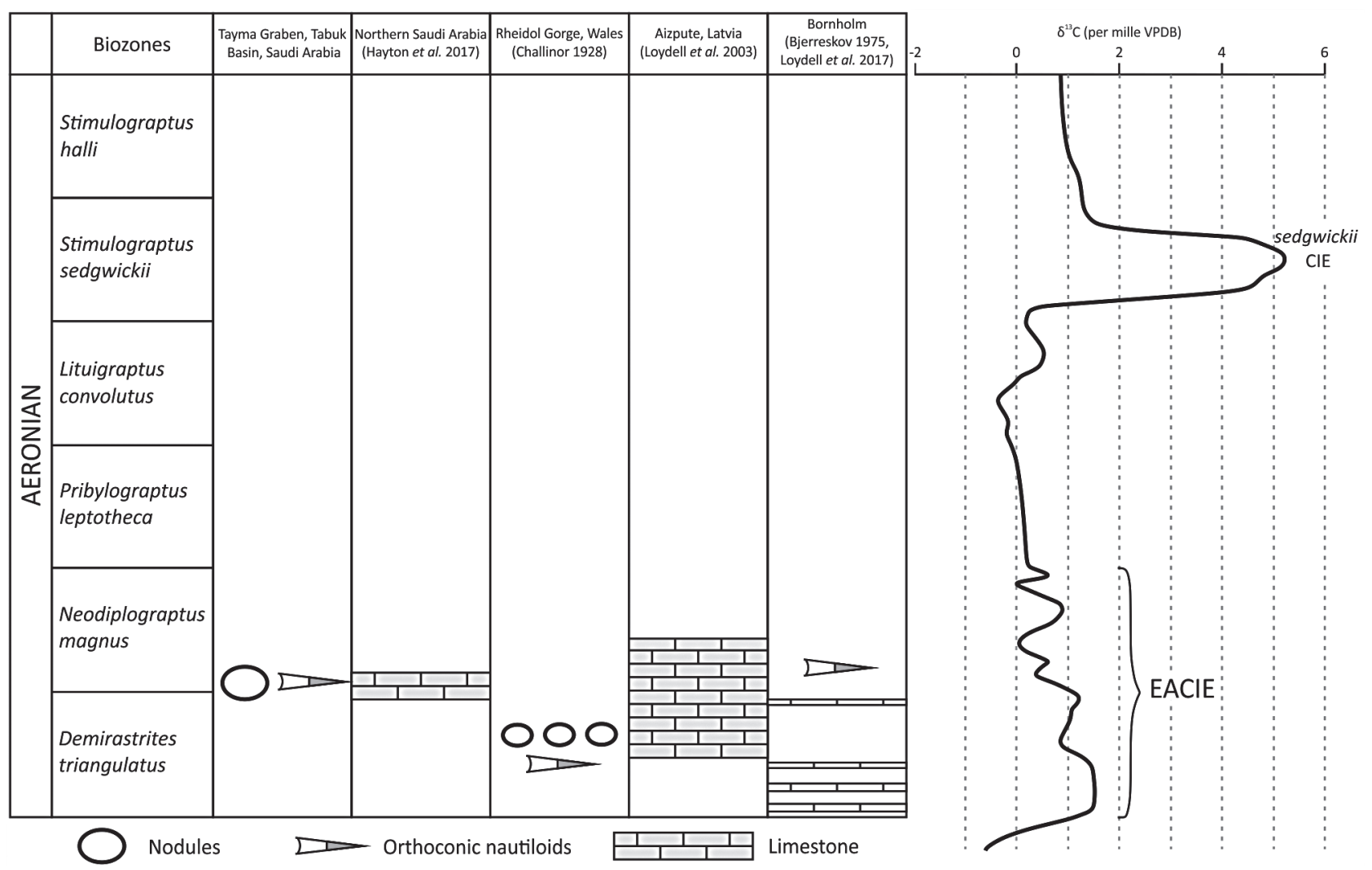

Figure 6. Occurrences of carbonate concretions/nodules and noteworthy abundances of preserved orthocones within the Aeronian of Saudi Arabia and other sections in Avalonia and Baltica. In all cases these are graptolitic deeper water shelf or basinal environments. The entirety of the Aeronian is shown to emphasize the stratigraphical restriction of these occurrences. A generalized carbon isotope curve for the Aeronian (modified from Melchin et al. 2020 to fit the biostratigraphical scale used herein) is shown to highlight that these carbonate occurrences are within a minor positive excursion (the EACIE). More dramatic facies changes are associated with the sedgwickii Excursion, including in central Saudi Arabia the widespread deposition of coarse clastics (the Mid-Qusaiba Sandstone of Miller \& Melvin 2005). Correlations are as precise as biostratigraphical data allow. What remains uncertain is whether the FAD of Neodiplograptus magnus is earlier in Gondwana and peri-Gondwanan Europe than on Avalonia and Baltica. This would affect the correlations slightly. Irrespective of this, it appears that environmental conditions in the early Aeronian favoured the formation of diagenetic calcium carbonate and the preservation of orthocones in some deeper water locations. 
Demirastrites pectinatus is recorded $21 \mathrm{~cm}$ above its top (Loydell et al. 2003).

The vast majority of lower Aeronian sections known, however, do not contain carbonates or an increased abundance of shelly fossils, so why the examples quoted here do, and whether this is more than just coincidental is uncertain.

\section{Early Aeronian environmental changes}

A small magnitude positive carbon isotope excursion (CIE) has been widely recorded in the lower Aeronian (e.g. Melchin \& Holmden 2006; Hammarlund et al. 2019 and references therein). This is referred to as the Early Aeronian Carbon Isotope Excursion (EACIE). As with other widely recognised CIEs, the EACIE presumably reflects globally significant environmental changes.

It is interesting that in the Hlásná Třebaň section, Czech Republic (peri-Gondwanan Europe) the peak $\delta^{13} \mathrm{C}$ value of the Early Aeronian Carbon Isotope Excursion (EACIE) is from the sample $1.5-1.6 \mathrm{~m}$ from the base of the section with Aeronian magnetic susceptibility also peaking at $1.6 \mathrm{~m}$, immediately below the first sample containing Neodiplograptus magnus (Štorch et al. 2018). The implication is that significant environmental changes, which appear to have commenced at the Rhuddanian-Aeronian boundary, reached their peak at this time here (and elsewhere) that are not obvious in the lithological record (other than through an increase in magnetic susceptibility), at the same time as carbonates were deposited and preserved in Saudi Arabia and in the sections in Avalonia and Baltica discussed above.

Facies changes indicate that other Hirnantian and Silurian positive CIEs are associated with a fall in sea level (e.g. Loydell 2007a). Other occurrences of Silurian limestones with cephalopods have also been linked to intervals of lowered sea-level (e.g. Ferretti \& Kříž 1995) and thus it is very tempting to suggest that a small fall in sea-level, insufficient to generate a significant lithofacies change in many sections (similar to the mid Rhuddanian sea-level fall discussed by Loydell et al. 2013 which had no lithological expression in the studied Libyan section), but prompting deposition and preservation of carbonate in others, occurred early in the Aeronian. This is not what is shown on the published sea-level curve of Loydell (1998, which also did not include the mid Rhuddanian fall in sea-level) - very little of the evidence (geochemical or lithological) had been published at that time. It appears that these more minor environmental changes, resulting in low magnitude isotope excursions, were insufficient to have a negative impact on graptolite diversity - the early Aeronian is associated with a major evolutionary radiation in the graptolites (and similar was ongoing in the mid Rhuddanian). The larger isotope excursions (early Sheinwoodian, mid Homerian, etc.), however, do all coincide with significant graptolite extinction events (Loydell 2007a).

\section{Source of the carbonate for the concretions}

Dissolution of some or all of the orthocone (or other) shells and local reprecipitation of the dissolved calcium carbonate seems the most likely explanation for the presence of the concretions at this level in the section. Cephalopod limestones are very well known from much higher in the Silurian (upper Wenlock to uppermost Prídolí) from peri-Gondwanan Europe (e.g. Ferretti \& Kř́ž 1995) and core Gondwana (e.g. Lubeseder 2008), but not the Arabian Plate, probably because of the development here of coarser clastics above the Llandovery shales. These nodules may represent a stratigraphically early, poorly developed expression of this cephalopod limestone facies.

Hayton et al. (2017) discussed the origin of the carbonate horizon(s) in the lower Aeronian of northern Saudi Arabia and considered the possibility of "total crystallization and stylotization" of a bioclastic deposit (which would be the first to have been observed in the Qusaiba Shale) as being responsible. Although this explanation was "not favored", there was further discussion of a biogenic origin. It was suggested that the preservation of shelly material might reflect the potential deepening of the CCD and that earlier in the Silurian because of cold temperatures, the CCD was shallower. This requires that the water depth on the Gondwanan shelf was sufficient for the depth of the CCD to have played a significant role in carbonate preservation. Boss \& Wilkinson (1991) concluded that the depth of the CCD from the Cambrian to Devonian was probably approximately $1-2 \mathrm{~km}$, significantly deeper than the tens to at most a few hundred metres water depth likely for these shelf seas, although the low temperatures at this high latitude and high atmospheric $\mathrm{CO}_{2}$ levels may perhaps have raised the CCD to such very shallow depths. It is worth noting also that a previous name for the Qusaiba Shale was the Climacograptus-Orthoceratid Member, stated to be characterized by the presence in its lower part of "numerous graptolites" and "several cephalopods" (Helal 1964, p. 408). Helal's log of his section 5 (approximately $200 \mathrm{~km}$ northeast of that studied herein and approximately $36 \mathrm{~km}$ north of Tabuk), however, recorded cephalopods from only one layer, $12.9 \mathrm{~m}$ above the highest recorded graptolites. If, however, cephalopods are present at more levels throughout the lower part of the member (as the member's name implies) then Hayton et al.'s (2017) sinking of the CCD proposal would become untenable. 


\section{Systematic Palaeontology}

\section{Genus Paraclimacograptus Přibyl, 1947 \\ (sensu Russel et al., 2000)}

\section{Paraclimacograptus crameri sp. nov.}

Figure $5 \mathrm{~A}-\mathrm{D}, \mathrm{F}$

Holotype. - BGS FOR 6323 (Fig. 5A) from the lowermost Neodiplograptus magnus Biozone (lower Aeronian), between the $10.5 \mathrm{~m}$ and $11.5 \mathrm{~m}$ level (graptolitic concretionary horizon), Qusaiba Shale Formation from the section exposed at $27^{\circ} 52^{\prime} 10^{\prime \prime} \mathrm{N}, 38^{\circ} 34^{\prime} 35^{\prime \prime} \mathrm{E}$, north-west of Tayma City, Saudi Arabia.

Material. - Five specimens, preserved diagenetically flattened with original periderm variably present. All are proximal ends, preserved in obverse view.

Etymology. - After Brad Cramer, who has done so much to reignite interest in the Silurian System.

Diagnosis. - Paraclimacograptus with conspicuously asymmetrical proximal end. Rhabdosome width $0.6-$ $0.75 \mathrm{~mm}$ at th $1^{1}$ and $1.1-1.45 \mathrm{~mm}$ at th $10^{1}$.

Description. - The rhabdosome is straight, the thecate portion up to $11.5 \mathrm{~mm}$ long. The proximal end is conspicuously asymmetrical resulting from the downward growth of th $1^{1} 0.3-0.4 \mathrm{~mm}$ below the sicular aperture. The sicula is $1.15-1.4 \mathrm{~mm}$ long, with an apertural width of $0.25 \mathrm{~mm}$. The sicular apex reaches to various levels on th $2^{1}$ : from half way up to the top. The virgella is thin, up to $0.4 \mathrm{~mm}$ long. Several thecae have pronounced geniculate flanges preserved. The thecal apertures are generally deep, comprising just under half of the rhabdosome width. The length of the apertures increases distally where it approaches the length of the preceding straight or more frequently slightly concave supragenicular wall. The nema is clearly seen within the rhabdosome of all specimens. It is an unmodified rod-like structure in three specimens, whereas in two (Fig. 5A, C) it appears to expand or perhaps be embedded within a (?partial) median septum originating at the level of the aperture of th $6^{2}$. Whatever this is, there is no trace of it at the distal end of the longer of the two rhabdosomes possessing this structure (Fig. 5A). Rhabdosome width measurements are as follows: $0.6-0.75 \mathrm{~mm}$ at th $1^{1}, 0.75-1.0$ mmat th $2^{1}, 0.8-1.15 \mathrm{~mm}$ at th $3^{1}, 1.15-1.3 \mathrm{~mm}$ at th $5^{1}$, and $1.1-1.45 \mathrm{~mm}$ at th $10^{1}$. Thecal spacing (2TRD, sensu Howe 1983) is $1.5-1.8 \mathrm{~mm}$ at th $2^{1}, 1.5-1.7 \mathrm{~mm}$ at th $3^{1}, 1.7-1.8 \mathrm{~mm}$ at th $5^{1}$, and $1.9-2.0 \mathrm{~mm}$ at th $10^{1}$.

Discussion. - Paraclimacograptus species are wellknown for exhibiting a high level of intraspecific variation in rhabdosome width (Štorch \& Massa 2006, Loydell 2007b). Although only a few specimens are known, $P a$. crameri would appear to be no exception to this. Despite this wide variation, $P a$. crameri is significantly narrower distally than Pa. libycus, the species that dominates the remainder of the Saudi graptolite assemblage. Štorch \& Massa (2006) recorded a rhabdosome width of $1.9-2.6 \mathrm{~mm}$ at the tenth thecal pair and Loydell (2007b) $1.7-2.55 \mathrm{~mm}$ at the same level (compared with $1.1-$ $1.45 \mathrm{~mm}$ at th $10^{1}$ in $P$ a. crameri). As noted by Štorch \& Massa (2006), Pa. brasiliensis (Ruedemann, in Maury 1929 ) is characterized by a largely parallel-sided, $2 \mathrm{~mm}$ wide rhabdosome, so is also significantly broader than Pa. crameri.

\section{Conclusions}

A layer of carbonate concretions within the Qusaiba Shale Formation, north-west of Tayma in north- west Saudi Arabia, is of early Aeronian (lowermost Neodiplograptus magnus Biozone) age. It contains a diverse (18 species) assemblage of graptolites, dominated by biserial taxa, many showing current alignment. The studied nodule included a $6 \mathrm{~mm}$ thick layer composed entirely of graptolites, potentially significant for the burial of organic carbon. Carbonates occur at a similar stratigraphical level in northernmost Saudi Arabia, suggesting a similar environmental origin. A few localities on Avalonia and Baltica, in sections otherwise dominated by outer shelf or basinal clastics, also have limestone layers and/or unusually high incidences of preservation of shells (mostly orthocones) within the lower Aeronian. It is considered likely that the limestone layers and nodules resulted from dissolution then reprecipitation of carbonate from some of the shelly fauna. This may be a stratigraphically very early and poorly developed expression of the cephalopod limestone facies so characteristic of higher levels in the Silurian of peri-Gondwanan Europe and Gondwana. Deposition and preservation of the carbonate occurred during the Early Aeronian Carbon Isotope Excursion (EACIE). One new species, Paraclimacograptus crameri, is described, distinguished from $\mathrm{Pa}$. libycus by its narrower rhabdosome.

\section{Acknowledgements}

Geoff Long and Richard Hing are thanked for cutting and polishing the carbonate concretion. Richard Hing also took some of the photographs. Roy Smith is thanked for assistance with the figures. Mark Williams and Sigitas Radzevičius are thanked for their constructive reviews of the original submission. 


\section{References}

Abouelresh, M. \& Babalola, L. 2020. 2D spatial analysis of the natural fractures in the organic-rich Qusaiba Shale outcrop, NW Saudi Arabia. Journal of Petroleum Science and Engineering 186, 106780.

DOI 10.1016/j.petrol.2019.106780

Abouelresh, M., Babalola, L., Bokhari, A., Omer, M., KoitHAN, T. \& Boyde, D. 2020. Sedimentology, geochemistry and reservoir potential of the organic-rich Qusaiba Shale, Tabuk Basin, NW Saudi Arabia. Marine and Petroleum Geology 111, 240-260. DOI 10.1016/j.marpetgeo.2019.05.001

Aoudeh, S.M. \& Al-HaJRI, S.A. 1995. Regional distribution and chronostratigraphy of the Qusaiba Member of the Qalibah Formation in the Nafud Basin, Northwestern Saudi Arabia, 143-154. In Al-Husseini, M.I. (ed.) Geo '94, The Middle East Petroleum Geosciences, Vol. 1. April 25-27 1994, Bahrain. Gulf PetroLink, Manama, Bahrain.

BJERRESKOV, M. 1975. Llandoverian and Wenlockian graptolites from Bornholm. Fossils and Strata 8, 1-94.

Boss, S.K. \& Wilkinson, B.H. 1991. Planktogenic/eustatic control on cratonic/oceanic carbonate accumulation. Journal of Geology 99, 497-513. DOI 10.1086/629513

Challinor, J. 1928. A shelly band in graptolitic shales. Geological Magazine 65, 364-368.

DOI 10.1017/S001675680010799X

Cullum, A.A. \& Loydell, D.K. 1996. A new species of Neodiplograptus from the Middle Llandovery of the Rheidol Gorge, Wales. Journal of the Czech Geological Society 41, 217-219.

Ferretti, A. \& KŘ́iž, J. 1995. Cephalopod limestone biofacies in the Silurian of the Prague Basin, Bohemia. Palaios 10, 240-253. DOI 10.2307/3515255

Ghavidel-Syooki, M., Álvaro, J.J., Popov, L., Ghobadi Pour, M., Ehsani, M.H. \& Suyarkova, A. 2011. Stratigraphic evidence for the Hirnantian (latest Ordovician) glaciation in the Zagros Mountains, Iran. Palaeogeography, Palaeoclimatology, Palaeoecology 307, 1-16.

DOI 10.1016/j.palaeo.2011.04.011

Halawani, M.A., Al-Duaij, A.A., Bahabri, B.H., Basyoni, M.H., Al Dabbagh, M.E., Al Ramadan, K., Al Ajmi, H.F., Al Mahri, A.K. \& Saudi Stratigraphic Committee Members 2013. Phanerozoic stratigraphy of Saudi Arabia: Part 1 Paleozoic succession of the Arabian Shelf (cover rocks). Saudi Geological Survey Special Publication SGS-SP-2012-1, $1-69$.

Hammarlund, E.U., Loydell, D.K., Nielsen A.T. \& Schovsbo, N.H. 2019. Early Silurian $\delta^{13} C_{\text {org }}$ excursions in the foreland basin of Baltica, both familiar and surprising. Palaeogeography, Palaeoclimatology, Palaeoecology 526, 126-135. DOI 10.1016/j.palaeo.2019.03.035

Hayton, S., Rees, A.J. \& Vecoli, M. 2017. A punctuated Late Ordovician and early Silurian deglaciation and transgression: evidence from the subsurface of northern Saudi Arabia. AAPG Bulletin 101, 863-886.

DOI 10.1306/08251616058

Helal, A.H. 1964. On the occurrence of Lower Palaeozoic rocks in Tabuk area, Saudi Arabia. Neues Jahrbuch für Geologie und Paläontologie, Monatshefte 7, 391-414.

Howe, M.P.A. 1983. Measurement of thecal spacing in graptolites. Geological Magazine 120, 635-638.

DOI 10.1017/S0016756800027795

JoNES, O.T. 1909. The Hartfell-Valentian succession in the district around Plynlimon and Pont Erwyd (North Cardiganshire). Quarterly Journal of the Geological Society of London 65, 463-537. DOI 10.1144/GSL.JGS.1909.065.01-04.32

Loydell, D.K. 1998. Early Silurian sea-level changes. Geological Magazine 135, 447-471. DOI 10.1017/S0016756898008917

Loydell, D.K. 2007a. Early Silurian positive $\delta^{13} \mathrm{C}$ excursions and their relationship to glaciations, sea-level changes and extinction events. Geological Journal 42, 531-546. DOI 10.1002/gj.1090

LOYDELL, D.K. 2007b. Graptolites from the Upper Ordovician and lower Silurian of Jordan. Special Papers in Palaeontology 78 , $1-66$.

LoYdeLL, D. K. 2011. Graptolite biostratigraphy of the E1-NC174 core, Rhuddanian (lower Llandovery, Silurian), Murzuq Basin (Libya). Bulletin of Geosciences 87, 651-660.

DOI 10.3140/bull.geosci.1311

Loydell, D.K., Butcher, A. \& FrÝdA, J. 2013. The middle Rhuddanian (lower Silurian) 'hot' shale of North Africa and Arabia: an atypical hydrocarbon source rock. Palaeogeography, Palaeoclimatology, Palaeoecology 386, 233-256. DOI 10.1016/j.palaeo.2013.05.027

Loydell, D.K. \& Large, R.R. 2019. Biotic, geochemical and environmental changes through the early Sheinwoodian (Wenlock, Silurian) carbon isotope excursion (ESCIE), Buttington Quarry, Wales. Palaeogeography, Palaeoclimatology, Palaeoecology 514, 305-325.

DOI 10.1016/j.palaeo.2018.10.028

Loydell, D.K. \& Maletz, J. 2004. The Silurian graptolite genera Streptograptus and Pseudostreptograptus. Journal of Systematic Palaeontology 2, 65-93.

DOI 10.1017/S1477201904001117

Loydell, D.K., Männik, P. \& Nestor, V. 2003. Integrated biostratigraphy of the lower Silurian of the Aizpute-41 core, Latvia. Geological Magazine 140, 205-229.

DOI 10.1017/S0016756802007264

Loydell, D.K., Walasek, N., Schovsbo, N.H. \& Nielsen, A.T. 2017. Graptolite biostratigraphy of the lower Silurian of the Sommerodde-1 core, Bornholm, Denmark. Bulletin of the Geological Society of Denmark 65, 135-160. DOI 10.37570/bgsd-2017-65-09

Lubeseder, S. 2008. Palaeozoic low-oxygen, high-latitude carbonates: Silurian and Lower Devonian nautiloid and scyphocrinoid limestones of the Anti-Atlas (Morocco). Palaeogeography, Palaeoclimatology, Palaeoecology 264, 195-209. DOI 10.1016/j.palaeo.2008.04.007

Lüning, S., Craig, J., Loydell, D.K., Štorch, P. \& Fitches, B. 2000. Lower Silurian "hot shales" in North Africa and Arabia: regional distribution and depositional model. EarthScience Reviews 49, 121-200.

DOI 10.1016/S0012-8252(99)00060-4 
Mahmoud, M.D., Vaslet, D. \& Husseini, M.I. 1992. The Lower Silurian Qalibah Formation of Saudi Arabia: an important hydrocarbon source rock. Bulletin of the American Association of Petroleum Geologists 76, 1491-1506. DOI 10.1306/BDFF8A24-1718-11D7-8645000102C1865D

MAury, C.J. 1929. Uma zona de graptolitos do Llandovery inferior no Rio Trombetas, Estado do Pará, Brasil. Servico Geologico e Mineralogico do Brasil, Monographia 7, 6-45.

McClure, H.A. 1988. The Ordovician-Silurian boundary in Saudi Arabia. Bulletin of the British Museum, Natural History (Geology) 43, 155-163.

Melchin, M.J. 1998. Morphology and phylogeny of some early Silurian 'diplograptid' genera from Cornwallis Island, Arctic Canada. Palaeontology 41, 263-315.

Melchin, M.J. \& Holmden, C. 2006. Carbon isotope chemostratigraphy of the Llandovery of Arctic Canada: implications for global correlation and sea-level change. GFF 128, 173-180. DOI 10.1080/11035890601282173

Melchin, M.J., Sadler, P.M. \& Cramer, B.D. 2020. The Silurian Period, 695-732. In Gradstein, F.M, OGG, J.G., Schmitz, M.D. \& OGG, G.M. (eds) Geologic time scale 2020. Volume 2. Elsevier BV, Amsterdam. DOI 10.1016/B978-0-12-824360-2.00021-8

Miller, M.A. \& Melvin, J. 2005. Significant new biostratigraphic horizons in the Qusaiba Member of the Silurian Qalibah Formation of central Saudi Arabia, and their sedimentological expression in a sequence stratigraphic context. GeoArabia $10,49-92$.

Pacкham, G.H. 1962. Some diplograptids from the British Lower Silurian. Palaeontology 5, 498-526.

PAŠKEvičIUS, J. 1976. On some new Llandoverian diplograptids of the eastern Baltic, 140-151. In KalJo, D. \& KorEN', T.N. (eds) Graptolites and stratigraphy. Tallinn.

PřIBYL, A. 1947. Classification of the genus Climacograptus
Hall, 1865. Bulletin International de l'Académie Tchéque des Sciences 48(2), 1-12.

Russel, J.C, Melchin, M.J. \& Koren', T.N. 2000. Development, taxonomy and phylogenetic relationships of species of Paraclimacograptus (Graptoloidea) from the Canadian Arctic and the southern Urals of Russia. Journal of Paleontology 74, 84-91. DOI 10.1017/S0022336000031267

ŠTorch, P. 2015. Graptolites from the Rhuddanian-Aeronian boundary interval (Silurian), Prague Synform, Czech Republic. Bulletin of Geosciences 90, 841-891. DOI 10.3140/bull.geosci.1568

Štorch, P., Manda, Š., TasÁryová, Z., FrÝda, J., Chadimová, L. \& Melchin, M.J. 2018. A proposed new global stratotype for Aeronian Stage of the Silurian System: Hlásná Třeban̆ section, Czech Republic. Lethaia 51, 357-388. DOI 10.1111/let.12250

ŠTorch, P. \& Massa, D. 2006. Middle Llandovery (Aeronian) graptolites of the western Murzuq Basin and Al Qarqaf Arch region, south-west Libya. Palaeontology 49, 83-112.

DOI 10.1111/J.1475-4983.2005.00530.X

Štorch, P. \& Melchin, M.J. 2018. Lower Aeronian triangulate monograptids of the genus Demirastrites Eisel, 1912: biostratigraphy, palaeobiogeography, anagenetic changes and speciation. Bulletin of Geosciences 93, 513-537.

DOI 10.3140/bull.geosci.1731

Torsvik, T. \& Cocks, L.R.M. 2013. New global palaeogeographical reconstructions for the Early Palaeozoic and their generation. Geological Society Memoirs 38, 5-24. DOI 10.1144/M38.2

Williams, M., Zalasiewicz, J., Boukhamsin, H. \& Cesari, C. 2016. Early Silurian (Llandovery) graptolite assemblages of Saudi Arabia: biozonation, palaeoenvironmental significance and biogeography. Geological Quarterly 60, 1-23.

DOI 10.7306/gq.1270 